\title{
DIAGNOSIS OF OSTEOPETROSIS IN ADULTS AFTER MANDIBULAR OSTEONECROSIS: CASE REPORT
}

Thyago Talles de Almeida Santana1,", Sanna Paula Pires Mariano Campos', Gabriela Almeida Barbosa, Robson Antônio Gonçalves ${ }^{1}$, Alessandra de Sousa Braz¹, Maria Roberta Melo Pereira Soares ${ }^{1}$, Eutília Andrade Medeiros Freire ${ }^{1}$

1. Universidade Federal da Paraíba, João Pessoa (PB), Brazil.

*Corresponding author: thyagotalles@hotmail.com

\section{BACKGROUND}

Osteopetrosis does not define a single disease, but a group of spectra that share similar characteristics resulting from its common pathogenesis: the increase in bone mass due to a resorption defect. It is a rare disease with a prevalence of up to 5.5/100,000 inhabitants. There are three main variants, among them the autosomal dominant adult form (ADO) or Albers-Schönberg disease, which is subdivided into ADO I (cranial involvement) and ADO II (changes in axial skeleton and long bones). They are characterized by osteomyelitis (often of the jaw), thickening of vertebral end plates (Rugger-Jersey spine), invasion of the medullary space with secondary cytopenias, hepatosplenomegaly (extramedullary hematopoiesis), compressive neuropathies.

\section{CASE REPORT}

A female patient, 53 years old, menopausal, insulin-dependent diabetic, started with left toothache and drainage of purulent secretion in July 2018. Dental evaluation showed a tooth abscess complicated with osteonecrosis of the jaw, treated with partial mandibular osteotomy and referred to rheumatology due to severe bone sclerosis on the mandibular radiography and left shoulder, hand and wrist pain. In September 2019, during rheumatological evaluation, she complained of left shoulder pain and paresthesia on the palmar side of the left hand, which, showed thenar atrophy on physical examination, positive Phalen maneuver and Tinel test, compatible with carpal tunnel syndrome, in addition to crepes in the semiotics of the left shoulder. Diagnostic propaedeutics was requested and brought bone densitometry with T-Score of L1-L4, femoral neck and total femur, respectively 11.4,10.1 and 8.1 (Fig. 1), which raised diagnostic suspicion for osteometabolic disease. On the return, she showed a left wrist ultrasonography with median nerve thickening, radiography of the spine with sclerosis of the end plates of the thoracic and lumbar vertebrae with the appearance of a "rugby shirt" (Fig. 2). Sclerosis of the cervical vertebrae with bone trabeculate loss (Fig. 3). On shoulder radiography: loss of cortex/spinal cord differentiation in the humerus, suggesting an image of "bone within bone" ("endobones") associated with important bone sclerosis (Fig. 4). Bone scintigraphy with technetium-99m demonstrating uptake in the mandible, skullcap, spine and long bones (Fig. 5). Laboratory with normocytic and normochromic hemoglobin 9.9 mg/dL, 25.9 OH vitamin-D 9.9 ng/mL, PTH 44.3 pg/mL (reference $10-65$ pg/mL), serum calcium 10 mg/dL, normal protein electrophoresis.

\begin{tabular}{|c|c|c|c|c|c|c|c|}
\hline Região & $\begin{array}{c}\text { Área } \\
\left(\mathrm{cm}^{2}\right)\end{array}$ & $\underset{(\mathrm{g})}{\mathrm{BMC}}$ & $\begin{array}{l}\text { DMO } \\
(\mathrm{g} / \mathrm{enp}) \mathrm{ntu}\end{array}$ & uaçẵo & $\begin{array}{l}\text { PR } \\
\text { (种)nt }\end{array}$ & Zaçấo & $\begin{array}{l}\mathrm{AM} \\
(\%)\end{array}$ \\
\hline LI & 12.51 & 29.55 & 2.363 & 12.5 & 239 & 13.3 & 262 \\
\hline 12 & 12.77 & 31.07 & 2.433 & 12.8 & 237 & 13.7 & 262 \\
\hline L3 & 14.62 & 34.05 & 2.328 & 11.3 & 215 & 12.3 & 237 \\
\hline 14 & 18.12 & 38.88 & 2.145 & 9.9 & 202 & 10.8 & 225 \\
\hline Total & 58.02 & 133.54 & 2.302 & 11.4 & 220 & 12.3 & 243 \\
\hline \multicolumn{8}{|c|}{ Resumo dos resultados de DXA: } \\
\hline gião & $\begin{array}{l}\text { Área } \\
\left(\mathrm{cm}^{2}\right)\end{array}$ & BMC & $\underset{\mathrm{g} / \text { cnpig)ntu }}{\text { DMO }}$ & Iaçẫo & $\begin{array}{l}\text { PR } \\
\text { (称)ntu }\end{array}$ & Z:- & $\begin{array}{l}\mathrm{AM} \\
(\%)\end{array}$ \\
\hline Pesc & 5.09 & 10.05 & 1.973 & 10.1 & 232 & 11.0 & 264 \\
\hline Total & 32.70 & 63.16 & 1.932 & 8.1 & 205 & 8.7 & 222 \\
\hline
\end{tabular}

Figure 1. Bone densitometry. 


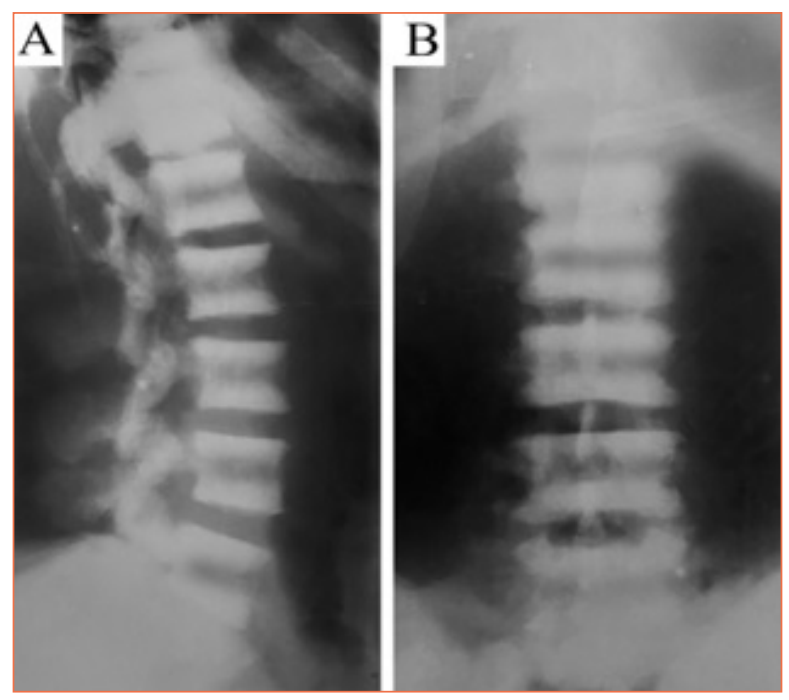

Figure 2. Lateral lumbar (A) and anteroposterior (B) spine radiography.

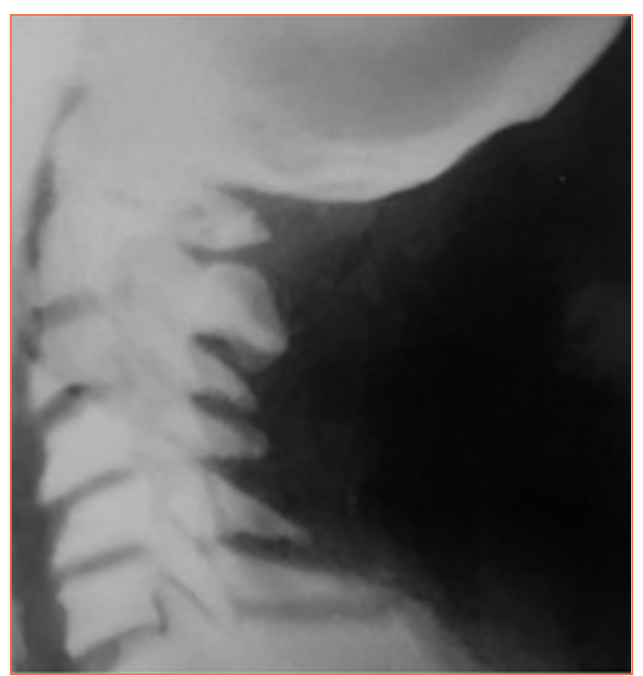

Figure 3. Lateral cervical spine radiography.
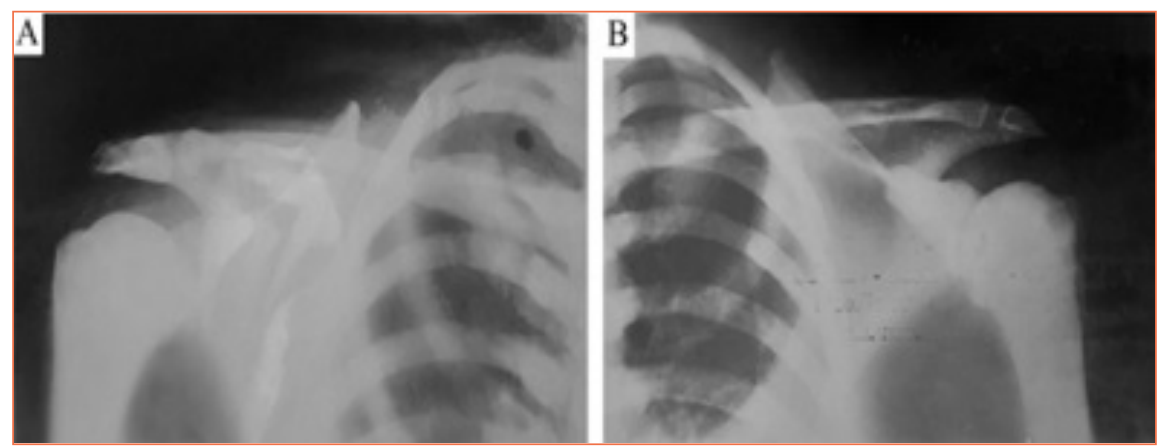

Figure 4. Radiography of the right $(A)$ and left $(B)$ shoulder. 


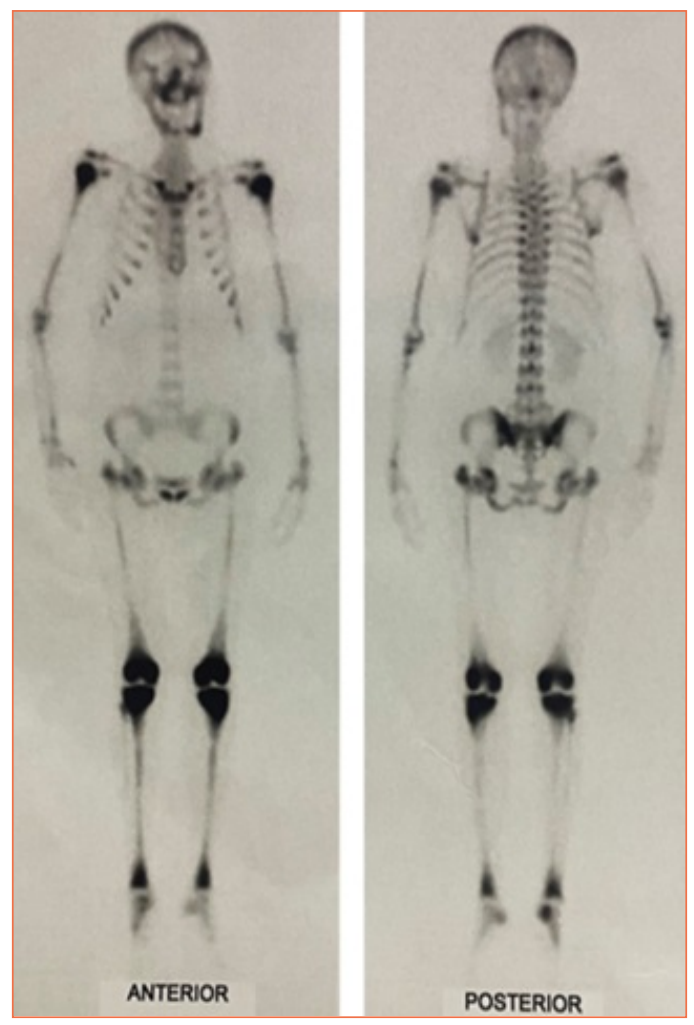

Figure 5. Bone scintigraphy.

\section{CONCLUSION}

Imaging findings added to the clinic and laboratory corroborate the diagnosis of osteopetrosis, an entity that although rare is expressed with classic findings that allow for diagnostic suspicion. Currently, there is no effective treatment, limiting therapy to clinical support. 